\title{
THE IMPORTANCE OF BLOG IN MARKETING COMMUNICATION
}

\author{
[Význam blogu v marketingovej komunikácii] \\ Milena Šimonidesová ${ }^{1}$, Petra Gundová ${ }^{2}$ \\ ${ }^{1}$ Univerzita Mateja Bela v Banskej Bystrici, Ekonomická fakulta, Tajovského 10, 97590 Banská Bystrica \\ Email: milena.simonidesova@studenti.umb.sk \\ ${ }^{2}$ Univerzita Mateja Bela v Banskej Bystrici, Ekonomická fakulta, Tajovského 10, 97590 Banská Bystrica \\ Email: petra.gundova@umb.sk
}

\begin{abstract}
The new technologies are offering new opportunities and challenges to the companies in marketing communication. Blogs are powerful tools of marketing communication and their proliferation has attracted substantial attention from marketing practitioners (academics as well as marketing managers). The companies have been encouraged to turn their attention from traditional marketing tools to social media, particularly blogs, because they can reach a large audience of existing and potential clients. The aim of this article is to find out if blog could be effective tool of marketing communication. For the purpose of the survey, method of questioning (questionnaire research) was utilised. The subject of the research was a sample of young people from 18 to 30 years old because the previous results of research demonstrate that the relevance of blogging in the buying process is particularly evident among buyers under 35 .
\end{abstract}

Keywords: blog, blog marketing, consumer behaviour, marketing communication, social media.

JEL classification: M30, M31

Doručeno redakci: 22.6.2018; Recenzováno: 1.7.2018; 2.7.2018; Schváleno k publikování: 19.9.2018

\section{Úvod}

V súčasnosti sociálne médiá poskytujú podnikom rozsiahly súbor nástrojov, prostredníctvom ktorých môžu cielene oslovit' svojich zákazníkov (Lee, Hong 2016). Špecifickost' jednotlivých platforiem umožňuje podnikom využivat' tvorivé a inovatívne marketingové stratégie sociálnych médií (Lee, Watkins 2016). Práve do oblasti sociálnych médií môžeme zaradit' aj blogy, ktorých potenciál narastá, nakol'ko majú vel'ký vplyv na verejnú mienku. Ked’že blogy predstavujú silný marketingový nástroj, blog marketing sa stáva stále viac a viac využívaný v podnikatel'skej praxi. Skúmaná problematika blogov a ich vplyv na zákazníkov bol predmetom výskumu niekol'kých štúdií (Hoffman, Fodor 2010; Kalampokis et al. 2013; Schoen et al. 2013)

Ciel'om predloženého príspevku je zistit' význam blogov ako marketingového nástroja a na základe výsledkov dotazníkového prieskumu identifikovat', do akej miery a akým spôsobom ovplyvňujú blogy nákupné správanie spotrebitel'ov od 18 do 30 rokov na Slovensku. Príspevok je členený do dvoch kapitol. V prvej kapitole zobrazujeme teoretické východiská blogov a blog marketingu. Druhá kapitola prezentuje výsledky uskutočneného dotazníkového prieskumu. Na základe zistených skutočností v závere príspevku uvádzame hlavné zistenia, ako aj obmedzenia uskutočneného prieskumu a jeho možné zlepšenia do budúcnosti.

\section{Teoretické východiská blogov}

Slovo blog vzniklo ako skratka $\mathrm{z}$ anglického slovného spojenia web log, čo vo svojej podstate znamená „denník na webovej stránke“. Prvý blog bol publikovaný na konci 20. storočia, kedy sa stal modernou inováciou a novým fenoménom (Janouch 2014). 
Blog môžeme považovat' za sociálne médium, ktoré sa vyznačuje osobitným systémom na riadenie obsahu. Z pohl'adu spoločnosti môžeme povedat', že blogy pomáhajú l'udom sa socializovat'. Oreský (2016) sa vyjadruje o blogu ako o sociálnom médiu, ktoré sa odlišuje od tradičných marketingových postupov. Tvrdí, že tento druh marketingu má svoje špecifiká. Považuje ho za dynamický a nekontrolovatel'ný. Rozhodujúcu úlohu prirad'uje spotrebitel'ovi, ktorého aktivity treba neustále sledovat', $\mathrm{z}$ dôvodu udržiavania dobrého online mena. Do pozornosti dáva aj náklady, ktoré sú v súvislosti s blogovaním nízke, kdeže blogy sa skôr vyznačujú pútavým obsahom, ktorý sa dokáže lepšie stretnút' s preferenciami ciel'ovej skupiny.

Blog je redakčný priestor na publikovanie článkov s možnost'ou spätnej väzby. Môžeme ho považovat' aj za sociálnu siet', pretože funguje na princípe softvéru na blogovanie a komunikovanie prostredníctvom komentárov a zdiel'ania príspevkov. Blogy napínajú dlhodobú potrebu l'udí vyjadrit' svoj názor, podelit' sa oň s ostatnými a navzájom medzi sebou na túto tému komunikovat'. Pôvodným účelom bolo vytvorenie osobného denníka $\mathrm{v}$ internetovom prostredí (Bednáŕ 2011, s. 165). Blogy majú svojich vlastných autorov pridávajúcich nové príspevky, takzvaných blogerov. Blog je väčšinou výsledkom práce jednej osoby, poprípade malej skupiny l'udí. Za blogera sa dnes považuje človek, ktorý píše osobný blog, zdiel'a svoje zážitky a myšlienky s verejnost'ou prostredníctvom vlastnej domény, svojej stránky alebo sociálnych sietí. Uvedený pojem v sebe zahŕňa viac ako len autora a editora článkov. Súčasný bloger sa musí stat' grafikom a fotografom, pretože vel'ké množstvo blogu pozostáva z obrázkov a videí. Musí predovšetkým vediet' zaujat' a prispôsobit' sa daným záujmom, preferenciám a trendom doby. Bloger by mal mat' jasnú predstavu o smerovaní blogu. Hned' na začiatku by si mal definovat' jeho ciel', ciel'ovú skupinu a jednotlivé témy, ktoré chce publikovat'. Rovnako sa musí zamerat' aj na propagáciu blogu.

Blogovanie je činnost' publikovania materiálov online, pravidelné pridávanie nových príspevkov a aktualizovanie blogu. Tieto príspevky sa nazývajú blogposty alebo len jednoducho posty. Blogpost je článok, ktorý je uverejnený online na webe v chronologickom poradí, teda najnovšie články sa po zverejnení zobrazujú ako prvé, pričom staršie príspevky postupne odsúvajú do archívu (Čonková 2015). Blogovanie spojilo dohromady silu konverzácie s obrovským skokom dopredu v jednoduchosti používania (Sterne 2011, s.16). V súčasnej dobe patrí blogovanie k rapídne sa rozvíjajúcej forme médií. Pre tisícky l'udí ide o prácu na plný úväzok, pričom počet blogerov narastá (Duermyer 2017). Pre podniky je to legálny spôsob prezentovat' ich produkty a služby. Blogovanie je jednoducho o tvorení online komunity, kde si dokonca l'udia $\mathrm{v}$ podobných situáciách môžu navzájom pomáhat'. Blogeri čoraz viac používajú svoj hlas v online svete, aby zmenili reálny svet. Vplyv určitých blogov v globálnych záležitostiach je dôkazom, že ich sila by všeobecne nemala byt' podceňovaná.

Miesto, kde sa stretávajú všetky blogy a blogeri, býva označované ako blogosféra. Je to neobmedzený priestor publikovania, nonstop sa rozrastajúci, vo všeobecnosti považovaný za komunitu blogerov. V širšom zmysle slova predstavuje všetky blogy, naopak, pri užšom zmysle sa pozeráme na diferencované skupiny blogov. Napríklad jednu z najpopulárnejších na Slovensku tvorí cestovatel'ská blogosféra. V roku 2017 sa najsledovanejším blogom v tomto odvetví stal blog s názvom TRAVELHACKER. Autorka blogu sa snaží priblížit' l'udom spôsoby ako cestovat' po svete viac, šikovnejšie a hlavne lacno'.

V súčasnosti sa môžeme stretnút's rôznou klasifikáciou blogov. Na základe hostingu (služba, ktorá poskytuje jednotlivcom, skupinám či organizáciám možnost' publikovat' webové stránky

\footnotetext{
${ }^{1}$ https://blogerroka.sk/2017/o-sutazi/
} 
na internet, technológia umožňujúca zobrazovanie internetových stránok na serveroch) členíme blogy na blogy bez vlastného hostingu a blogy s vlastným hostingom ${ }^{2}$. Autor Oreský (2016) rozoznáva blogy prevádzkované podnikmi a používatel'ské blogy. V predloženom príspevku sa prikláňame k nasledujúcemu členeniu:

- osobné blogy,

- firemné blogy (používané ako forma online PR),

- blogy organizácií (štátne a neziskové),

- žánrové blogy (venujúce sa špecifickej téme ako napríklad cestovanie, móda a podobne),

- blogy podl'a média (video blogy, fotoblogy a podobne) ? $^{3}$.

V súvislosti s problematikou blogov sa čoraz častejšie stretávame s termínom blog marketing. Blog marketing predstavuje proces propagujúci podnik alebo konkrétnu značku či službu prostredníctvom blogov. Zarad'ujeme sem reklamy umiestnené na blogoch, odporúčania a recenzie od blogerov, ako aj propagáciu blogov na iných webových stránkach. Reklama na blogu má podobu internetových bannerov, odkazov, videí, audio nahrávok či rôznych animácií. Rovnako môže byt' prezentovaná len samotným textom. Pozitívna recenzia od obl'úbeného blogera, poskytnutie jeho skúsenosti s daným produktom alebo službou, názor, môže taktiež ovplyvnit' príjmy podnikov. Podniky rovnako platia populárnym blogerom aj za spomenutie daného produktu vich príspevku, resp. jeho ukážku. Blog marketing má množstvo výhod, ako aj nevýhod. Na jednej strane môže predstavovat' ideálnu príležitost' dostat' sa do povedomia spotrebitel'ov a na strane druhej, situáciu, ktorú už nie je možné zmenit'. Jeho nekontrolovatel'nost' nad šírenou správou ho robí riskantným.

Momentálnym trendom je aj vzájomná spolupráca blogera s konkrétnou značkou, s ktorou má uzatvorenú formu partnerstva v podobe PR spolupráce. Ďalší spôsob predstavuje spojenie blogera s kolekciou príslušnej organizácie alebo vydanie jemu vlastnej produktovej rady. Ide o tzv. merchandising, ktorý predstavuje jeden zo základných nástrojov marketingu.

\section{Výsledky dotazníkového prieskumu}

V tejto časti príspevku prezentujeme výsledky dotazníkového prieskumu, ktorý prebiehal v termíne od 17.2.2018 do 7.3.2018. Ciel'om dotazníkového prieskumu bolo zistit' význam blogov ako marketingového nástroja a identifikovat', do akej miery a akým spôsobom ovplyvňujú blogy nákupné správanie spotrebitel'ov od 18 do 30 rokov na Slovensku. Z predchádzajúcich prieskumov vyplýva, že blogy majú vplyv na spotrebitel'ské správanie (Ho et al. 2015; Chen, Lin 2015; Dehghani et al. 2016). V predloženom príspevku sme sa pre segment mladých l'udí rozhodli z viacerých dôvodov. Pre mladých l’udí sú sociálne siete samozrejmou ich života (Liljander et al. 2015). Podl'a Boltona a kol. (2013) je pravdepodobnejšie, že používatelia sociálnych sietí a médií vo veku od 18 do 34 rokov v porovnaní so staršími vekovými kategóriami uprednostnia na komunikáciu so svojimi známymi, priatel'mi a rodinou práve sociálne siete. $Z$ predchádzajúcich výskumov tiež vyplýva (Kelly a kol. 2010), že mladí l'udia prestávajú dôverovat' tradičnej reklame, pričom práve blogy sa pre nich stávajú dôležitým zdrojom informácií. Navarro a López-Rúa (2016) uvádzajú, že význam blogov $\mathrm{v}$ procese nákupu je obzvlášt' evidentný medzi mladšími zákazníkmi do 35 rokov, ktorí považujú blogy za primárny zdroj informácií pri nákupe.

Na tvorbu dotazníka bol použitý nástroj Google Docs. Dotazník bol šírený v elektronickej podobe cez sociálnu siet' Facebook, pričom bol zverejnený na študentskej stránke Ekonomickej fakulty Univerzity Mateja Bela v Banskej Bystrici, ako aj v skupinách, ktoré sa

\footnotetext{
${ }^{2}$ https://www.website.com/beginnerguide/webhosting/6/1/what-is-web-hosting?.ws

${ }^{3} \mathrm{http}: / /$ design.krea.sk/clanky/blogy/
} 
priamo zaoberajú riešením problematiky internetu a online poradenstva. Na základe danej skutočnosti šírenia dotazníka nie je možné stanovit' návratnost' prieskumu, nakol'ko nevieme ku kol'kým respondentom sa dostal.

Dotazník obsahoval 26 otázok, ktoré boli rozčlenený do viacerých častí. Prvá čast’ predstavuje identifikačné otázky. Pozostáva zo štyroch otázok zist’ujúcich faktografické údaje o respondentoch (pohlavie, vek, súčasný stav a najvyššie dosiahnuté vzdelanie). Druhá čast' dotazníka sa už priamo zameriava na všeobecné informácie o blogoch. V závislosti od odpovedí v tejto časti sa mohli respondenti ocitnút' pred jednou z dvoch možností. Pokial' blogy nesledujú, dostali sa do poslednej časti dotazníka, zameranej na dôvody nesledovania blogov. Naopak, ak blogy sledujú, poslednou čast'ou dotazníka sme zistovali vplyv blogov na nákupné správanie respondentov. Výberový súbor predstavoval 217 respondentov, ktorých základné identifikačné údaje prezentuje nasledujúca tabul'ka 1.

Tabul'ka 1: Identifikačné údaje výberového súboru

\begin{tabular}{|c|c|c|}
\hline Charakteristika & Počet respondentov & Percentuálne vyjadrenie \\
\hline \multicolumn{3}{|l|}{ Pohlavie } \\
\hline žena & 140 & $64,50 \%$ \\
\hline muž & 77 & $35,50 \%$ \\
\hline \multicolumn{3}{|l|}{ Vek } \\
\hline $18-20$ rokov & 36 & $16,60 \%$ \\
\hline $21-23$ rokov & 73 & $33,60 \%$ \\
\hline $24-26$ rokov & 57 & $26,30 \%$ \\
\hline $27-30$ rokov & 51 & $23,50 \%$ \\
\hline \multicolumn{3}{|l|}{ Súčasný stav } \\
\hline študent & 88 & $40,60 \%$ \\
\hline zamestnaný & 100 & $46,10 \%$ \\
\hline nezamestnaný & 9 & $4,20 \%$ \\
\hline iné & 20 & $9,20 \%$ \\
\hline \multicolumn{3}{|c|}{ Najvyššie dosiahnuté vzdelanie } \\
\hline základné & 15 & $6,90 \%$ \\
\hline stredoškolské bez maturity & 8 & $3,70 \%$ \\
\hline stredoškolské s maturitou & 128 & $59,00 \%$ \\
\hline vysokoškolské I. stupeň & 29 & $13,40 \%$ \\
\hline vysokoškolské II. stupeň & 35 & $16,10 \%$ \\
\hline vysokoškolské III. stupeň & 2 & $0,09 \%$ \\
\hline
\end{tabular}

Zdroj: Spracované na základe výsledkov dotazníkového prieskumu.

Výberový súbor pozostáva zo 140 žien a 77 mužov. V rámci vzdelania jednoznačne vyniklo úplné stredoškolské vzdelanie s maturitou, ktoré udalo 128 respondentov (59 \%). Po identifikačných otázkach sme zist'ovali, či sa respondenti stretli s pojmom blog a zároveň, čo podl'a nich daný termín predstavuje. Len štyria respondenti uviedli, že sa s daným slovom ešte nestretli a d'alší piati uviedli, že nevedia, alebo si nepamätajú, či prišli do styku s blogom. Zvyšných 208 respondentov (95,9 \%) uviedlo, že s daným termínom už do kontaktu prišlo a tento pojem bližšie charakterizovalo 139 z nich. Najčastejšie si l'udia pod slovom blog predstavujú internetový denník pozostávajúci zo zážitkov, názorov a trendov. Definujú ho ako osobný webový portál, ktorého vlastník a autor spočívajú v jednej osobe. Vidia v ňom formu vyjadrenia, ktorá poskytuje vol'nost' a prit’ahuje pozornost'. Dokonca niektorí považujú blog za nástroj zarábania peňazí, generovania príjmov. Jeden z respondentov uvádza, že „blog je nekonvenčným zdrojom informácií, ktorý nepodlieha tlaku finančných skupín ani tlaku politikov. V súčasnosti začína fungovat' ako nástroj dosiahnutia vyváženosti spravodajstva a 
môže sa stat' cenným zdrojom noviniek, trendov, postojov...“ Niektorí naopak v blogu vidia spôsob publikovania, kde sa jasne odráža trend pravidelného písania článkov ako aktualizácia webového denníka.

Nasledujúca čast' dotazníka sa priamo zaoberala motívmi, či už sledovania alebo nesledovania blogov. Vychádzajúc z výsledkov prieskumu môžeme povedat', že až približne $52 \%$ respondentov blogy nesleduje (72 žien a 40 mužov). V rámci danej kategórie sme sa respondentov prostredníctvom otvorenej otázky pýtali na ich dôvody nesledovania blogov. Zistené dôvody sme roztriedili do siedmych skupín uvedených v tabul'ke 2.

Tabul'ka 2: Dôvody nesledovania blogov

\begin{tabular}{|l|c|c|}
\hline Charakteristika & Počet respondentov & Percentuálne vyjadrenie \\
\hline Iné záujmy & 27 & $24,10 \%$ \\
\hline Nedostatok času & 25 & $22,32 \%$ \\
\hline Nedôvera & 18 & $16,07 \%$ \\
\hline Nezáujem sledovat' blogy & 17 & $15,18 \%$ \\
\hline Nenašli také, ktoré by ich bavilo pravidelne sledovat' & 10 & $8,93 \%$ \\
\hline Strata času & 7 & $6,25 \%$ \\
\hline Neviem & 8 & $7,14 \%$ \\
\hline
\end{tabular}

Zdroj: Spracované na základe výsledkov dotazníkového prieskumu.

Niektorí z respondentov považujú blogy za príliš statické, ale hlavne ich nepovažujú za spôsob zábavy či strávenia vol'ného času, ktorý by sa kryl s ich preferenciami. Ako d’alšiu významnú príčinu uvádzali nedostatok času, ku ktorej inklinovali skôr muži. Uvedený dôvod jednoznačne súvisí s dnešnou uponáhl'anou dobou, v rámci ktorej po splnení povinností spojených s prácou, rodinou či det'mi neostáva vel'a vol'ného času. Tretiu najvýznamnejšiu príčinu nesledovania blogov respondenti uviedli nedôveru $\mathrm{v}$ ich obsah či názory blogerov. L'udia vidia v pozadí recenzií platenú reklamu, ktorá vychádza zo spolupráce blogera a firmy. Častokrát sa im blog javí ako prostriedok ovplyvňovania nevedomých l'udí a nepovažujú ho za relevantný zdroj informácií. Písanie blogov pokladajú len za sebarealizáciu bez ohl'adu na hodnotu ich obsahu. Pre niektorých sú blogy príliš „mainstreamové“ a radšej sa venujú odborným článkom, ktoré pre nich poskytujú hodnotnejšie informácie. Ako d’alšie dôvody uviedli nezáujem sledovat' taký typ stránok, či nenájdenie konkrétnych blogov, ktoré by sa stali predmetom ich záujmu. Čast' respondentov uviedla, že blogy považuje za zbytočné mrhanie času.

Zvyšných $48 \%$ respondentov zúčastnených v dotazníkovom prieskume sa vyjadrilo, že s blogmi prichádza pravidelne do kontaktu. V uvedenej kategórii sme zist'ovali, aké podnety nútia l'udí opätovne navštevovat' blogy a čo považujú za ich najzaujímavejšiu čast'. Pri spracovávaní výstupov sme vybrali ku každej spomenutej otázke tri najčastejšie sa vyskytujúce odpovede, ktoré sme rozobrali. Skúmaná vzorka respondentov ako základné motívy opätovných návštev blogov uviedla získanie nových informácií, ktoré označilo 87 respondentov (55 žien a 32 mužov) a zámer blogu (65 respondentov, z toho 38 žien a 27 mužov). Ďalším výrazným prvkom je skutočnost', že l'udia na blogoch hl'adajú spôsob zábavy a relaxu, čo považuje za primárny motív 52 respondentov. Uvedenú trojkombináciu častejšie uvádzali ženy. Pri mužoch vychádza do popredia hlavne motív nových informácií, ktoré sú pre nich primárnym podnetom, pre ktorý blogy vôbec vyhl'adávajú. Vychádzajúc z dotazníkového prieskumu môžeme povedat', že najfrekventovanejším motívom návratu na blog sú nové informácie. Zostat' informovaný je dôležitou súčast'ou dnešného každodenného života. 
Z hl'adiska atraktívnosti blogu považujú respondenti za dôležité prvky zaujímavé témy, osobnost' blogera a kvalitu písania. Z dotazníkového prieskumu jasne vyplynulo, že l'udí najčastejšie na blog prit’ahujú zaujímavé témy, ktoré označilo 74 respondentov (44 žien a 30 mužov). Tie pútajú pozornost' a zabezpečujú tak neustále rastúcu sledovanost'. Zároveň respondenti oceňujú jedinečnost' (59 respondentov), ktorú blogeri vkladajú do svojich príspevkov. Tá sa častokrát stáva aj ich osobným podpisom, na základe ktorého je možné uvedených jedincov aj rozoznávat'. Ich osobnosti sú potom predmetom sledovania, ktoré odrážajú ich autenticitu, s čím súvisí aj samotný spôsob prezentácie blogu, ktorý sa vyznačuje hlavne kvalitou písania blogera (54 respondentov). Respondenti považujú kvalitu písania za dôležitý prvok blogu, ktorý ovplyvňuje dížku pobytu stráveného na uvedených stránkach. To znamená, že čím pútavejšie a jedinečnejšie dokáže bloger prezentovat' svoju prácu, tým viac čitatel'ov dokáže získat' a zároveň aj udržat'. Rovnako je pre neho dôležité zadefinovat' presný obsah blogu, s čím samozrejme súvisí aj stanovenie samotného ciel’a či výber hlavnej témy, ktorou sa blog bude zaoberat'. Preto sme sa v nasledovnej časti dotazníka zaujímali aj o to, k akému druhu blogov respondenti inklinujú najviac. V otázke sme uviedli klasifikáciu blogov podl'a sút’aže Bloger Roka 2017 s doplnením o kategóriu iné, pričom počet odpovedí sme nelimitovali.

Obrázok 1: Sledované druhy blogov

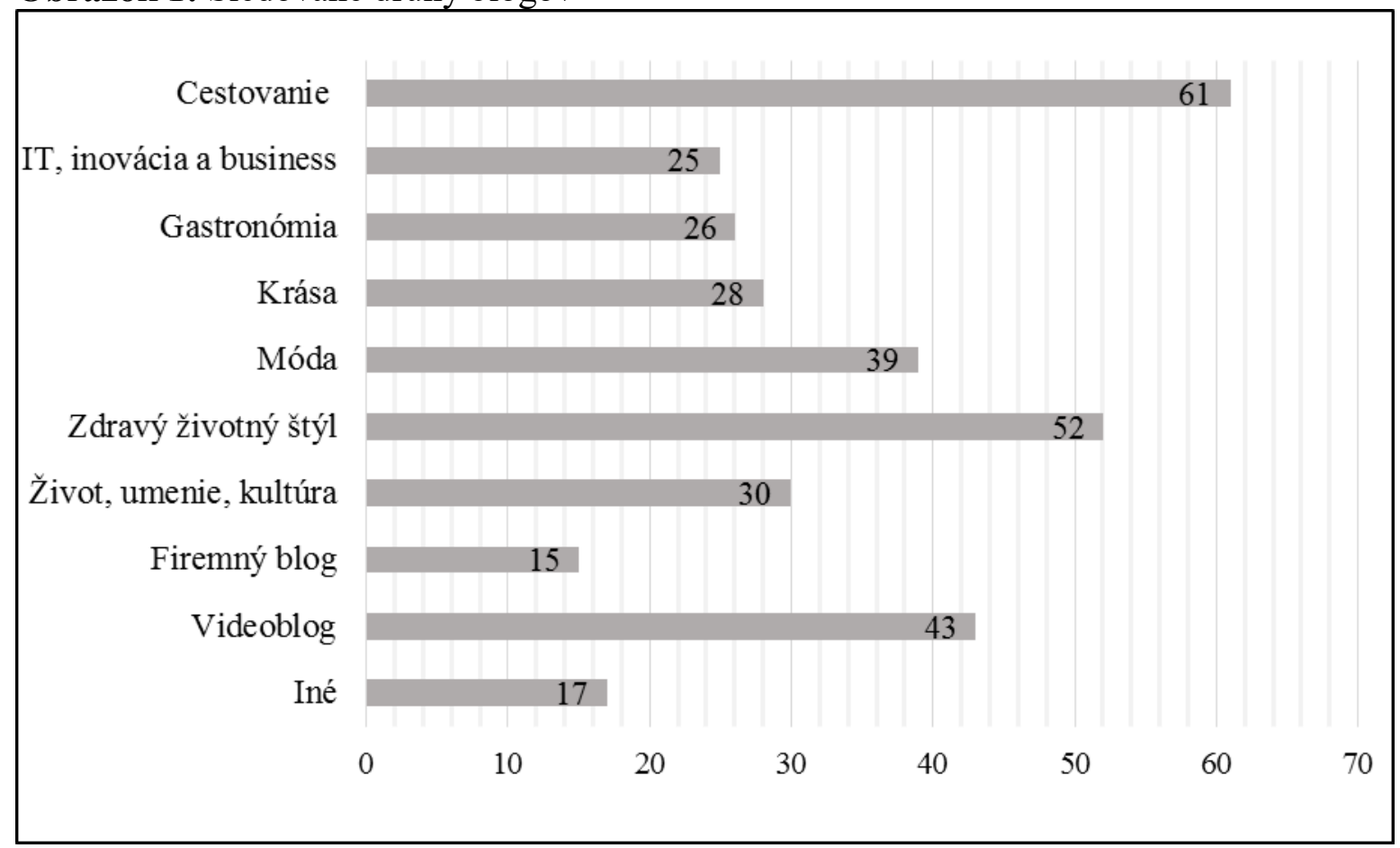

Zdroj: Spracované na základe výsledkov dotazníkového prieskumu.

Podl'a vyššie uvedeného obrázka môžeme povedat', že účastníci dotazníkového prieskumu najviac sledujú blogy, ktoré sa zameriavajú na tematiku cestovania (61 respondentov). Uvedený jav môže súvisiet' aj so samotnou sút'ažou Bloger Roka 2017, kde sa vít’azom stal práve blog z oblasti cestovania. Na druhom mieste sa nachádzal blog, ktorý sa venuje zdravému životnému štýlu (52 respondentov). V súčasnosti sa do popredia dostávajú aj videoblogy, tzv. vlogy, ktoré označilo 43 respondentov.

Spomínané druhy blogov respondenti najčastejšie navštevujú niekol'kokrát za týždeň, čo uviedlo skoro $41 \%$ respondentov. Danú kategóriu tvoria prevažne študentky vo veku od 21 až 23 rokov. Približne $24 \%$ účastníkov dotazníkového prieskumu, ktorí blogy sledujú, uviedlo, 
že sa na blogy vracajú niekol'kokrát za deň, či už z dôvodu zábavy alebo získania potrebných informácií. Pravidelnost' návštevnosti konkrétneho blogu sa teda odvíja hlavne od jedinečnosti obsahu, ktorý zaručuje, aké množstvo l’udí danej ciel'ovej skupiny dokáže blog pritiahnut'. Rovnako aj samotný čas strávený na blogu sa odvíja od viacerých faktorov, pričom je zrejmé, že čím viac bloger publikuje, tým významnejšie dokáže zaujat' pozornost' svojich čitatel'ov. S uvedenou skutočnost'ou súvisí aj kvalita uverejňovaných formátov. Dnešní mladí l'udia sú v súvislosti s obsahom vel'mi nároční a zároveň požadujú neustále nové nápady a prezentácie zo strany blogerov. Ich záujem o blog je potom vyjadrovaný ich pravidelnost'ou návštev. Môžeme povedat', že ak bloger pravidelne aktualizuje svoju stránku zaujímavými a prínosnými formátmi, zaručuje si stabilnú návštevnost' v dlhodobom časovom horizonte.

Obrázok 2: Faktory ovplyvňujúce rozhodovanie spotrebitel’ov

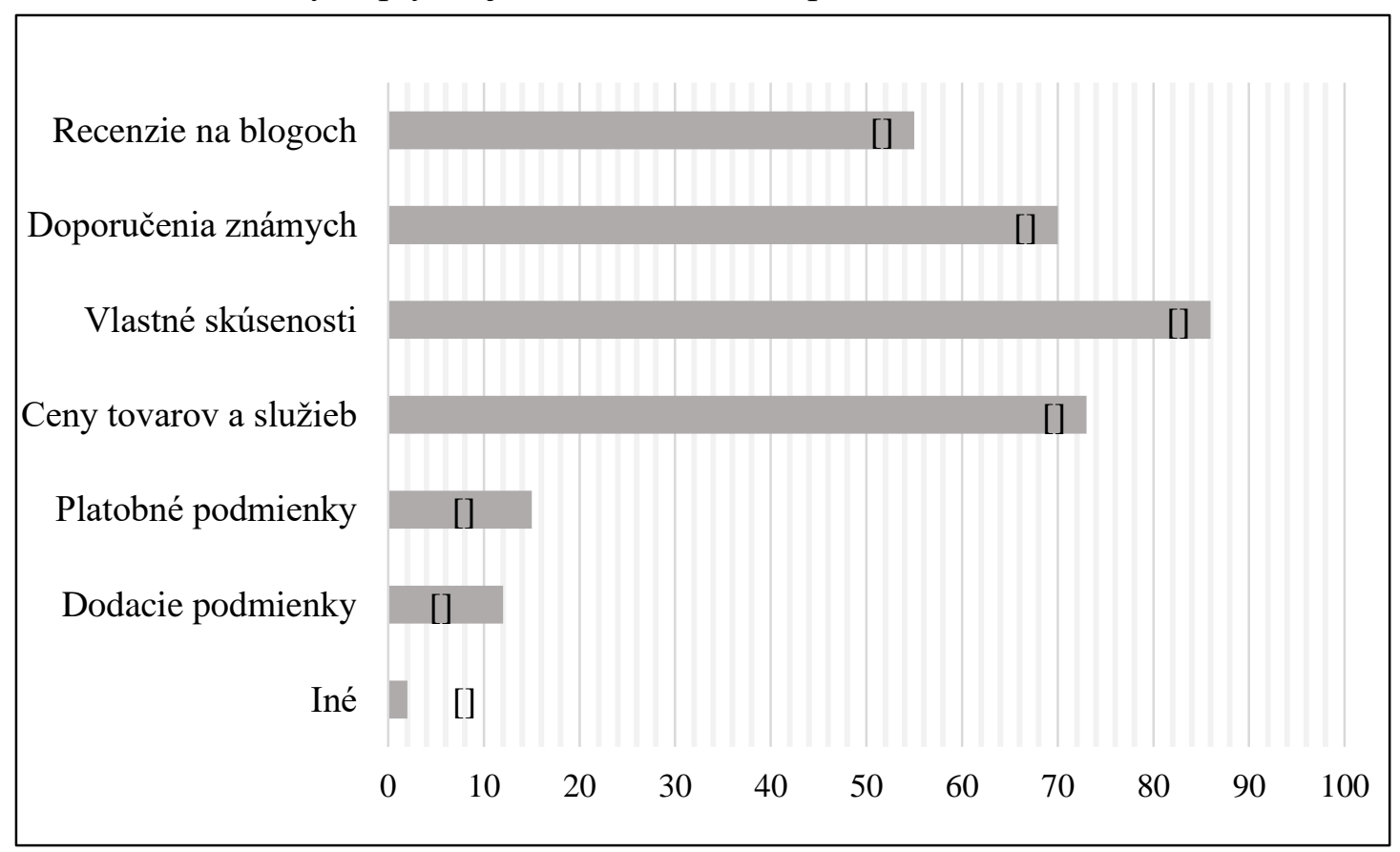

Zdroj: Spracované na základe výsledkov dotazníkového prieskumu.

V poslednej časti dotazníka sme sa zaoberali len priamym dosahom blogov na nákupné správanie mladých l'udí. Prostredníctvom otázok sme rozoberali, aké vplyvy mladí l'udia zvažujú pri rozhodovaní o kúpe jednotlivých produktov. Zostavili sme otázky, ktoré nám pomohli tieto dosahy jasnejšie priblížit'. Najskôr sme zist'ovali, aké aspekty vstupujú do rozhodovacieho procesu kúpy, pričom vychádzali sme z počtu respondentov, ktorí blogy sledujú (105 respondentov). Zároveň sme stanovili limit na možnost' výberu, a to tri odpovede. $Z$ výsledkov je jednoznačné, že mladí l'udia sa rozhodujú na základe svojich vlastných skúseností, čo uviedlo približne $82 \%$ účastníkov ( 86 respondentov). Rozhodujú sa teda na základe svojej racionality a zároveň v tomto procese berú do úvahy rôzne vedomé aj nevedomé faktory, ktoré tiež vplývajú na ich činy. Z obrázka 2 jasne vychádza, že d’alším činitel'om vplyvu je cena, ktorú zvolilo 73 zo 105 respondentov, teda skoro $70 \%$. V tejto súvislosti musíme spomenút' aj d'alší aspekt, ktorý dost' podstatne zasahuje do spotrebitel'ského správania, a to zárobky respondentov. Tí sa potom snažia čo najlepšie využit' svoje zdroje, a preto sú citlivejší na cenu, z čoho zretel'ne vychádza aj jej dôležitost'. Tretím významným impulzom sú aj odporúčania známych. Rodina je jedným zo silných aspektov, ktorá pôsobí na mladých l'udí a núti ich prispôsobovat' sa jej názorom. Dosah rodinných príslušníkov, kamarátov, kolegov či spolužiakov jasne definovalo 70 zo 105 
účastníkov dotazníka (66,7 \%), preto môžeme povedat', že ide o zásadné ovplyvňovanie aj po stránke emócií. Recenzie z blogov sa umiestnili ako štvrtý faktor vplyvu, čo znamená, že viac ako $50 \%$ respondentov si je vedomých, že pri kúpe produktov a služieb zvažuje aj názor, ktorý si prečítali na blogu. Je zrejmé, že aspoň čast' spotrebitel'ov považuje blogy za zdroj relevantných informácií, ktoré potom využíva.

Blogy sú pre istú skupinu l’udí pomocným faktorom v procese rozhodovania, o čom svedčí aj fakt, že $76 \%$ respondentov (zo 105, ktorí blogy sledujú) uviedlo, že na blogoch našlo potrebné informácie a d'alších 19,2 \% z časti našlo to, čo potrebovalo. Len 4,8 \% vyjadrilo, že hl'adané informácie nenašlo a zároveň vyjadrilo skutočnost', že názor blogera pre nich podstatný nie je, respektíve nepotrebujú ho poznat', pretože sa na základe neho nerozhodujú.

Prostredníctvom jednej z otázok sme zvažovali aj možnost' priameho vplyvu blogov naviest' l'udí na potrebu niečo si kúpit', pričom z výsledkov je zrejmé, že približne 55 respondentov tento predpoklad potvrdilo. Najčastejšie nakupujú na základe recenzií kozmetiku, oblečenie či navštevujú miesta (reštaurácie, kaviarne a pod.), na ktoré blogeri robia reklamu. S nákupmi podloženými odporúčaniami blogera bola väčšina spotrebitel’ov spokojná ( $91 \%$ vyslovilo svoj pozitívny názor). Zároveň potvrdili aj skutočnost', že informácie na blogoch ich naozaj podnecujú ku kúpe rôznych produktov, či spotrebe služieb.

Následne sme zist'ovali názory respondentov na platené reklamy, na základe ktorých blogeri prezentujú uvedené produkty. Respondenti uviedli, že takýto typ spolupráce má byt' vždy riadne označený a rovnako by mal bloger sám túto skutočnost' oznámit' svojmu čitatel'ského publiku. Znamená to, že každá spolupráca by mala byt' jasne a zrozumitel'ne prezentovaná ako typ reklamy, či merchandising. Blogeri bývajú sponzorovaní rôznymi značkami, poprípade si podniky vyberajú svojich ambasádorov, ktorí daný produkt alebo značku dlhodobo odporúčajú prostredníctvom ich osobnosti. Je teda zrejmé, že mladí l'udia nie sú úplne stotožnení $\mathrm{s}$ takýmto typom reklamy. $\mathrm{Z}$ ich pohl'adu sa pozeráme na vlnu nedôveryhodnosti, ktorá odráža skutočnost', že blogeri častokrát prikrášl'ujú svoje názory $\mathrm{v}$ prospech sponzorov. Vel'akrát je tu silný motív finančného zárobku, ktorý odzrkadl'uje aktivitu vynaloženú na spropagovanie danej veci. Tá sa mnohokrát stáva aj dôvodom, ktorý vytvára v l'ud'och pochybnosti o samotnom blogerovi. Vplyv uvedenej spolupráce medzi blogerom a značkou zastupujúcou podnik sme d’alej overovali v nasledujúcich súvislostiach. 32 respondentov vyjadrilo, že vplyv značiek pri kúpe tovarov a služieb nepocituje. 23 účastníkov dotazníkového prieskumu v rámci likertovej škály uviedlo stupeň 3 , takže $\mathrm{k}$ dosahu daných značiek pristupujú neutrálne. 50 respondentov si je vedomých vplyvu jednotlivých značiek, ktoré sú spomenuté v rôznych videách a článkoch. Častokrát sú spropagované veci novinkami na trhu, ktoré sa v očiach spotrebitel'ov stávajú predmetom záujmu. Samotný vplyv vychádza z rôznych príčin, pričom za najčastejšiu by sme mohli označit' trendovost', ktorá núti mladých l'udí neustále nakupovat' a prispôsobovat' sa súčasným smerom orientovaným v móde, hudbe, zábave a pod.

Tabul'ka 3: Najčastejšie používané sociálne siete na sledovanie blogov

\begin{tabular}{|l|c|c|}
\hline Sociálna siet' & Počet respondentov & Percentuálne vymedzenie \\
\hline YouTube & 58 & $70,70 \%$ \\
\hline Facebook & 65 & $79,30 \%$ \\
\hline Instagram & 55 & $67,10 \%$ \\
\hline Snapchat & 4 & $4,90 \%$ \\
\hline Twitter & 2 & $2,40 \%$ \\
\hline Iné & 6 & $7,30 \%$ \\
\hline
\end{tabular}

Zdroj: Spracované na základe výsledkov dotazníkového prieskumu. 
Prostredníctvom dotazníkového prieskumu sme sa zaujímali aj o to, či respondenti sledujú blogerov na sociálnych siet'ach (tabul'ka 3). Stanovený jav nám nepotvrdilo až 23 respondentov, čo môže vyplývat' z rôznych, avšak nami nezist'ovaných dôvodov. Naopak pri 82 respondentoch sme sa stretli s kladnou odpoved'ou. Mladí l'udia majú potrebu sledovat' život svojich oblúbených blogerov, pričom sociálne siete im umožňujú byt' s nimi v kontakte takmer neustále. Častokrát sa z takéhoto spojenia chcú dozvediet' súkromnejšie informácie o nich a zároveň spoznat' ich každodenný život. Poprípade využívajú sociálne siete na samotnú možnost' komunikácie s nimi. Vychádzajúc $\mathrm{z}$ výsledkov dotazníkového prieskumu, mladí l'udia najčastejšie na sledovanie života obl'úbených blogerov používajú sociálnu siet' Facebook, ktorú označilo 65 respondentov, ako uvádza tabul'ka 3. 58 respondentov sleduje blogerov na sociálnej sieti YouTube. Ďalšou špecifickou sociálnou siet'ou je aj Instagram, ktorý pracuje s fotografiami, respektíve mini videami nazývanými „instastories“. Používanie tohto média na pravidelné sledovanie blogerov uviedlo až 55 respondentov.

Respondenti v dotazníkovom prieskume sami vyjadrili skutočnost', že blogy sú pre nich naozaj prospešné z hl'adiska pozície spotrebitel'a, čo vyjadrilo skoro $88 \%$ respondentov (v absolútnom vyjadrení 92 respondentov). Ďalších 9 respondentov ich pokladá za vel'mi dôležitý aspekt, ktorý im pomáha rozhodovat' sa pri realizácii nákupov tovarov a služieb. Len 4 respondenti považujú blogy za neprospešné, pričom dôvody sme d’alej nezist'ovali.

Podobné vyjadrenie sme získali aj k otázke, či sú blogy podl'a spotrebitel'ov dôležitým marketingovým nástrojom zameriavajúcim sa prvotne na segment mladých l'udí. Výsledky danej otázky môžeme vidiet' v tabul'ke 4. Respondenti ich považujú prevažne za dôležité, čo môže vychádzat' aj zo skutočnosti, že mladí l'udia považujú blogy za bežnú súčast' ich života. 32 účastníkov sledujúcich blogy ich vidí ako vel'mi dôležitý marketingový nástroj. Vd'aka internetu máme ovel'a jednoduchší prístup k produktom, preto aj ich samotná prezentácia zohráva podstatnú úlohu. Spotrebitelia si potom uvedomujú, že podniky sa snažia prispôsobit' ich potrebám, pričom budujú si image a získavajú potenciálnych klientov.

Tabul'ka 4: Dôležitost' blogov ako marketingového nástroja

\begin{tabular}{|l|c|c|}
\hline Charakteristika & Počet respondentov & Percentuálne vymedzenie \\
\hline Vel'mi dôležitý & 32 & $30,50 \%$ \\
\hline Skôr dôležitý & 51 & $48,60 \%$ \\
\hline Skôr nedôležitý & 21 & $20,00 \%$ \\
\hline Nedôležitý & 1 & $1,00 \%$ \\
\hline
\end{tabular}

Zdroj: Spracované na základe výsledkov dotazníkového prieskumu.

Z výsledkov dotazníkového prieskumu vyplynulo, že blogy naozaj vstupujú do rozhodovacieho procesu spotrebitel'ov pri kúpe tovarov a služieb. Je zrejmé, že toto sociálne médium vplýva nielen pozitívne, ale aj negatívne, pričom je na blogeroch nájst' tú správnu cestu k svojim čitatel’om.

\section{Záver}

V posledných rokoch je stále viac rozšírené využívanie sociálnych sietí, dôsledkom čoho podniky v rámci marketingovej komunikácie prechádzajú od tradičných nástrojov $\mathrm{k}$ online médiám a prispôsobujú sa tak súčasným trendom na trhu. Vd’aka internetu sa následne povedomie o ich produktoch šíri čoraz $\mathrm{k}$ väčšiemu množstvu l'udí. Práve $\mathrm{z}$ daného dôvodu podniky začali využívat' blogy ako nástroj, ktorý im značne pomáha rozvíjat' vzt'ahy s ich zákazníkmi a budovat' image. Sledovanie blogov je typické najmä pre mladú generáciu zákazníkov. Jedným z dôvodov môže byt' skutočnost', že blog je výborný spôsob na 
sledovanie toho, čo zákazníkov baví. Dôležitým faktorom by však mala byt' autentickost'. Články na blogoch by mali byt' osobné a mali by obsahovat' informácie, ktoré čitatel'om blogov niečo prinesú, či už je to zábava alebo inšpirácia (konkrétne kritériá závisia od zamerania samotného blogu).

Ciel'om predloženého príspevku bolo zistit', význam blogov ako marketingového nástroja a na základe výsledkov dotazníkového prieskumu identifikovat' do akej miery a akým spôsobom ovplyvňujú blogy nákupné správanie spotrebitel'ov od 18 do 30 rokov na Slovensku. Blog ako marketingový nástroj je primárne určený pre podniky, ktoré sa neustále snažia prezentovat' svoje produkty a služby zákazníkom, teda byt' s nimi v kontakte. Sú využívané malými aj strednými podnikmi, ako aj nadnárodnými spoločnost’ami,, ktoré si uvedomujú ich potenciál. Zameranie týchto podnikov sa sústred’uje najmä na módu a kozmetiku. Rovnako vstupujú do pozornosti podnikov aj cestovatel'ské blogy. Zároveň sa $\mathrm{v}$ uvedených okruhoch podniky sústred'ujú primárne na mladých l'udí, pričom svoju pozornost' orientujú viac na ženy, pre ich náchylnost' podliehat' okolitým vplyvom. Podniky ich využívajú hlavne kvôli dôvere, ktorú si k týmto sociálnym médiám dokázali mladí l'udia vytvorit'. Podobne sa snažia zužitkovat' ich popularitu a prepojenost' na trh. Blogy v súčasnosti predstavujú efektívny nástroj zviditel'nenia podniku, či samotných produktov, ktorý dokáže pozitívne vplývat' na tržby daného podniku.

Za najväčšie obmedzenie predloženého príspevku považujeme nereprezentatívnu vzorku respondentov (nereprezentatívnost' výberového súboru bola daná aj tzv. pohodlnou vzorkou respondentov), v dôsledku čoho nebolo možné výsledky prieskumu zovšeobecnit' na celý základný súbor. Obmedzenia štúdie vytvárajú príležitosti pre budúci výskum, v rámci ktorého bude možné uskutočnit’ aj híbkové štatistické analýzy.

\section{Literatúra}

[1] BEDNÁR̆, V., 2011. Internetová publicistika. Praha: Grada Publishing. ISBN 978-80247-3452-1.

[2] Blog ako ideálny komunikačný kanál pre osobné a firemné účely. [online]. [vid. 5. apríla 2018]. Dostupné z: http://design.krea.sk/clanky/blogy/

[3] Bloger roka 2017. [online]. [vid. 4. apríla 2018] Dostupné z: https://blogerroka.sk/2017/o-sutazi/

[4] BOLTON, R. A. et al., 2013. Understanding generation Y and their use of social media: a review and research agenda. Journal of Service Management, 24(3), 245-267. ISSN 1757-5818.

[5] ČONKOVÁ, M., 2015. História blogov a blogovania, alebo kde sa vzal blog [online]. [vid. 4. mája 2018]. Dostupné z: http://projektblogoblogu.blogspot.sk/2015/01/historiablogov-blogovania-alebo-kde-sa.html

[6] DEHGHANI, M. et al., 2016. Evaluating the influence of YouTube advertising for attraction of young customers. Computer in Human Behavior, 59, 165-172. ISSN 07475632.

[7] DUERMYER, R., 2017. Blog Marketing: What Is It and How to Do It. How to Use a Blog to Promote and Grow Your Home Business. [online]. [vid. 5. apríla 2018]. Dostupné z: https://www.thebalance.com/blog-marketing-1794404 
[8] HO, CH. et al., 2015. Can internet blogs be used as an effective advertising tool? The role of product blog type and brand awareness. Journal of Enterprise Information Management, 28(3), 346-362. ISSN 1741-0398.

[9] HOFFMAN, D. L. and M. FODOR, 2010. Can you measure the ROI of your social media marketing? Sloan Management Review, 52(1), 41-49. ISSN 1532-9194.

[10] CHEN, S. and CH. LIN, 2015. The impact of customer experience and perceived value on sustainable social relationship in blogs: An empirical study. Technological Forecasting \& Social Change, 96, 40-50. ISSN 0040-1625.

[11] JANOUCH, V., 2014. Internetový marketing. Bratislava: Computer Press. ISBN 978-80251-4311-7.

[12] KALAMPOKIS, E. et al., 2013. Understanding the predictive power of social media. Internet Research, 23(5), 544-559. ISSN 1066-2243.

[13] KELLY, L. et al., 2010. Avoidance of advertising in social networking sites. A teenage perspective. Journal of Interactive Advertising, 10(2), 16-27. ISSN 1525-2019.

[14] LEE, J. and I. B. HONG, 2016. Predicting positive user responses to social media advertising: The roles of emotional appeal, informativeness, and creativity. International Journal of Information Management [online]. 36(1), 360-373 [vid. 4. apríla 2018]. ISSN 0268-4012. Dostupné z: http://dx.dois.org/10.1016/j.ijinfomgt.2016.01.001.

[15] LEE, J. E. and B. WATKINS, 2016. YouTube vloggers' influence on consumer luxury brand perceptions and intentions. Journal of Business Research [online]. 69(1), 57535760 [vid. 4. mája 2018]. ISSN 0148-2963. Dostupné z: http://dx.doi.org/10.1016/j.busres.2016.04.171

[16] LILJANDER, V. et al. 2015. Young consumers' responses to suspected covert and overt blog marketing. Internet Research, 25(4), 610-630. ISSN 1066-2243.

[17] NAVARRO, G. M. and M. de G. LÓPEZ-RÚA, 2016. The influence of blogs in fashion in consumer behaviour: an exploratory approach. Revista de Comunicación Vivat Academia [online]. 19(135), 85-109 [vid. 4. mája 2018]. ISSN 1575-2844. Dostupné z: http://dx.doi. org/10.15178/va.2016.135.85-109

[18] ORESKÝ, M., 2016. Aplikovaný marketing. Bratislava: Wolters Kluwer. ISBN 978-808168-382-4.

[19] STERNE, J., 2011. Měríme a optimalizujeme marketing na sociálních sítích. Brno: Computer Press. ISBN 978-80-251-3340-8.

[20] SCHOEN, H. et al., 2013. The power of prediction with social media. Internet Research, 23(5), 528-543. ISSN 1066-2243.

[21] What is Web Hosting. [online]. [vid. 4. apríla 2018]. Dostupné z: https://www.website.com/beginnerguide/webhosting/6/1/what-is-web-hosting?.ws 